\title{
Simultaneous Nitrification and Denitrification using Activated Sludge Entrapped in Polyethylene Glycol Prepolymer
}

\author{
TATSUO SUMINO*, KAZUICHI ISAKA, HAJIME IKUTA, and BASSEM OSMAN \\ Matsudo Research Laboratory, Hitachi Plant Technologies \\ /537 Kami-hongo, Matsudo, Chiba, 271-0064, Japan
}

\begin{abstract}
To develop a simultaneous nitrification and denitrification system using activated sludge entrapped in a polyethylene glycol prepolymer (PEG-entrapped activated sludge), optimization of operating conditions of dissolved oxygen (DO) and oxidation-reduction potential (ORP) were investigated, and ammonium load and the influent $\mathrm{C} / \mathrm{N}$ ratio using optimized aeration-limited processes in which there is repeated alternation of aeration and non-aeration were examined. Continuous wastewater treatment was carried out using a synthetic wastewater containing ammonium nitrogen and sodium acetate as a carbon source. ORP was not significant, and absolute anaerobic conditions were not indispensable for simultaneous nitrification and denitrification. Nitrogen removal ratio was not improved even if microaerophilic conditions of DO ranging from 0.2 to $0.6 \mathrm{mg} / l$ were provided under continuous treatment. Fluctuations in DO using aeration-limited processes were effective in improving performance. The nitrogen removal ratio of the aeration-limited processes was higher than in continuous aeration and in conventional activated sludge. The aerationlimited processes using PEG-entrapped activated sludge were effective in obtaining more than $80 \%$ nitrogen removal at an ammonium loading rate of $0.08-0.12 \mathrm{~kg}-\mathrm{N} / \mathrm{m}^{3} / \mathrm{d}$ and a $\mathrm{C} / \mathrm{N}$ ratio of over 2.5 with sodium acetate as a carbon source.
\end{abstract}

Key words: nitrogen removal, simultaneous nitrification and denitrification, PEGentrapped activated sludge, aeration-limited process

\section{INTRODUCTION}

Nitrogenous compounds are major pollutants in some aquatic environments. Nitrate and ammonia are most often of concern in eutrophication, that is, in algal blooms in lakes, rivers, and reservoirs. Ammonia in wastewater is normally eliminated by a combination of the two processes of nitrification and denitrification using an anoxic-aerobic activated-sludge system. Nitrification is achieved by the complete oxidation of ammonia to nitrate, and denitrification is achieved by the subsequent reduction of nitrate to $\mathrm{N}_{2}$ gas under anoxic conditions at the expense of organic matter.

Nitrogen removal systems using PEGentrapped activated sludge have been developed and are currently in use at 14 domestic wastewater treatment facilities in Japan. ${ }^{1-3)}$ PEG-entrapped activated sludge are placed into nitrifying tanks and nitrifying bacteria grow at high density in the pellet so that high rates of nitrification can be obtained. However, this system requires the construction of two large reactors, one for the nitrification tank and the other for the denitrification tank. Therefore the initial costs for construction are high. If nitrogen removal

\footnotetext{
${ }^{*}$ Corresponding author

e-mail: tatsuo.sumino.cj@hitachi-pt.com

Telephone: +81-(0)-47-361-6101,

Facsimile: +81-(0)-47-361-6107
} 
could be performed in a single reactor in which simultaneous nitrification and denitrification takes place, a more reliable and economical process would be possible.

Recently, a number of papers have been published on simultaneous nitrification and denitrification. Single-stage nitrogen removal methods are more economical than conventional methods using an anoxic-aerobic activated-sludge system. These methods use, for example, a sequencing bath, ${ }^{4)}$ a single process using immobilized nitrifying and denitrifying bacteria, ${ }^{5-7)}$ and a $\mathrm{CANON}^{8)}$ or SNAP $^{9,10)}$ process using anammox bacteria.

To develop a single reactor using nitrifying bacteria and denitrifying bacteria, anoxic and aerobic zones are required in the reactor. Immobilized pellets using entrapment methods are feasible for aerobic surface zones and anoxic inner zones. Recently, we confirmed that nitrifying and denitrifying bacteria grew in large numbers and were dominant in PEG-entrapped activated sludge in a nitrification tank used in domestic wastewater treatment. ${ }^{2}$ ) If simultaneous nitrification and denitrification could be performed, a more stable and economical process would be possible. Therefore, this study was performed to evaluate a singlestage nitrogen removal using PEG-entrapped activated sludge. The effects of DO, ORP, ammonium loading and the influent $\mathrm{C} / \mathrm{N}$ ratio on nitrogen removal were investigated.

\section{MATERIALS AND METHODS}

\section{PEG-entrapped activated sludge}

Pellets of PEG-entrapped activated sludge were collected from a demonstration nitrification tank at a domestic wastewater treatment facility in Saitama Prefecture, Japan. The facility is an anoxic/oxic nitrogen removal system. Pellets were $3 \mathrm{~mm}$ cubes. Initial concentrations of activated sludge entrapped in PEG were $2 \%$. Pellets were placed in a nitrifying tank, and stable nitrification was observed for 1.2 years. In the pellets, $7.8 \times 10^{7}$ cell $\mathrm{s} / \mathrm{m} l$ of ammonium oxidizing bacteria (AL counts), $3.4 \times 10^{6}$ cells/ $\mathrm{m} l$ of ammonium oxidizing bacteria (AH counts), and $7.4 \times 10^{6}$ cell $\mathrm{s} / \mathrm{m} l$ of denitrifying bacteria were found to be viable. Values are the counts of viable bacteria (cells) per carrier $(\mathrm{m} l)$. The AL and $\mathrm{AH}$ counting methods are described in analytical methods. Operational conditions and nitrification performance of the demonstration plant on sampling day are shown in Table 1.

\section{Synthetic wastewater}

The composition of synthetic wastewater used in continuous treatment tests was as follows: $\mathrm{NH}_{4} \mathrm{Cl}, 76.4 \mathrm{mg} / \mathrm{l} ; \mathrm{NaHCO}_{3}, 234 \mathrm{mg} / l$; $\mathrm{Na}_{2} \mathrm{HPO}_{4} \cdot 12 \mathrm{H}_{2} \mathrm{O}, 23.1 \mathrm{mg} / l ; \mathrm{NaCl}, 10.1 \mathrm{mg} / l$; $\mathrm{KCl}, 4.7 \mathrm{mg} / l ; \mathrm{CaCl}_{2} \cdot 2 \mathrm{H}_{2} \mathrm{O}, 4.7 \mathrm{mg} / l$; and $\mathrm{MgSO}_{4} \cdot 7 \mathrm{H}_{2} \mathrm{O} 16.7 \mathrm{mg} / \mathrm{l}$. This contained $\mathrm{NH}_{4}{ }^{-}$ $\mathrm{N}$ at $20 \mathrm{mg} / l$. To operate under various $\mathrm{C} / \mathrm{N}$ ratios for denitrification, sodium acetate was added to the synthetic wastewater at $\mathrm{C} / \mathrm{N}$ ratios of $1.4^{-4}$.

\section{Wastewater treatment equipment}

ORP control equipment The equipment used to measure the effects of ORP on nitrogen removal in a single $400-\mathrm{ml}$ tank is shown in Fig. 1. Pellets of PEG-entrapped activated sludge were placed in the tank at a packing ratio of $20 \%$. Synthetic wastewater flowed into the bottom of the reactor, and effluent flowed through a polyvinyl chloride screen with $2-\mathrm{mm}$ holes to separate the pellets from the effluent. The lower and upper ORP limits were set by an ORP controller (OR10, Shibata, Tokyo). Aeration (aeration rate of $5 \mathrm{l} / \mathrm{min}$ ) was started at the lower limit, and it was stopped at the upper limit. Agitation of pellets was continuously performed by an agitator (model Heido-N,

Table 1 Operating conditions in demonstration plant.

\begin{tabular}{cc}
\hline Item & Condition \\
\hline Influent wastewater & $2,220 \mathrm{~m}^{3} /$ day \\
Volume of denitrification tank & $400 \mathrm{~m}^{3}$ \\
Volume of nitrification tank & $300 \mathrm{~m}^{3}$ \\
Volume of pellets in nitrification tank & $23 \mathrm{~m}^{3}$ \\
Retention time in nitrification tank & $3.2 \mathrm{~h}$ \\
Recycling ratio* & 3 \\
Influent $\mathrm{NH}_{4}-\mathrm{N}$ & $18 \mathrm{mg} / l$ \\
Effluent $\mathrm{NH}_{4}-\mathrm{N}$ & $0.4 \mathrm{mg} / l$ \\
Temperature of nitrification tank & $24{ }^{\circ} \mathrm{C}$ \\
DO of nitrification tank & $3.2 \mathrm{mg} / l$ \\
\hline
\end{tabular}

*Recycling ratio from nitrification tank to denitrification tank 


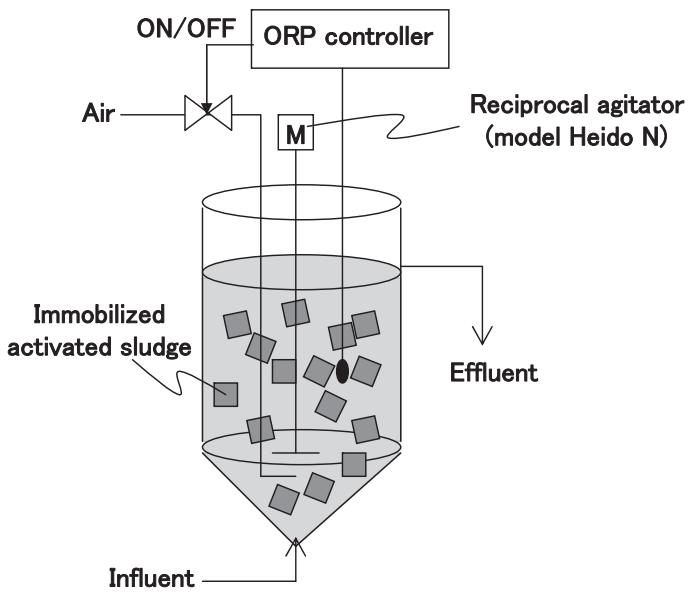

Fig. 1 ORP control equipment using aeration control.

Nippon Seiki Co., Tokyo). The agitation was by vertical vibration so as not to subject the pellets to severe shearing forces.

Aeration-limited control equipment The equipment used to measure the effects of repeatedly alternating aeration and nonaeration on nitrogen removal in a single $400-\mathrm{m} l$ tank is shown in Fig. 2. Pellets of PEG-entrapped activated sludge were placed in the tank at a packing ratio of $20 \%$. Synthetic wastewater flowed into the bottom of the reactor, and effluent overflowed through a screen to separate the pellets from the effluent. The non-aeration and aeration durations (aeration rate of $5 \mathrm{l} / \mathrm{min}$ ) were set by a timer. Agitation of the carrier was continuous.

Continuous aeration equipment Continuous aeration was carried out by the same aeration-limited control equipment described above. The DO in the tank was set to be $0.2-4.0 \mathrm{mg} / \mathrm{l}$ by adjusting aeration quantity.

Conventional activated sludge equipment Activated sludge processing equipment is shown in Fig. 3. Activated sludge at 2,000 $\mathrm{mg} / \mathrm{l}$ was placed in the equipment, and synthetic wastewater flowed from the upper part of the reactor. Aeration was performed at $5 \mathrm{l} / \mathrm{min}$.

\section{Optimization of operating conditions}

Effects of ORP on nitrogen removal ORP was controlled by ON/OFF control of aeration

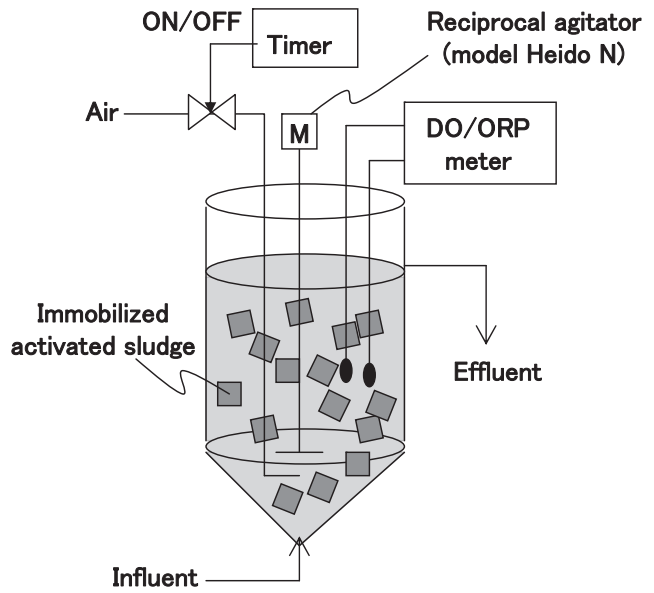

Fig. 2 Aeration-limited control equipment using alternating aeration and non-aeration.

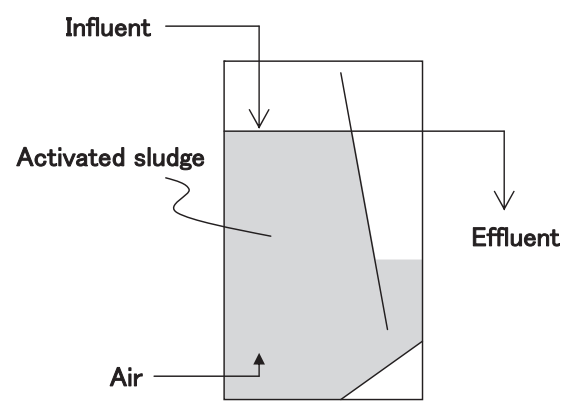

Fig. 3 Conventional activated sludge equipment.

(aeration rate of $5 \mathrm{l} / \mathrm{min}$ ) to set lower and upper limits using the ORP-control equipment (Fig. 1). ORP controlled ranges were 0-63, 40-140, 100-170, and 200-240 mV in four stages. Treatments were performed under each set of conditions at a retention time of 6 $\mathrm{h}$ and a load of $0.08 \mathrm{~kg}-\mathrm{N} / \mathrm{m}^{3} / \mathrm{d}$.

Effects of DO on nitrogen removal The DO in the tank was set to be $0.2-4.0 \mathrm{mg} / l$ by adjusting the aeration quantity using the continuous aeration equipment. The total nitrogen $(\mathrm{T}-\mathrm{N})$ removal rate under each set of conditions was obtained. Treatments were carried out at a retention time of $6 \mathrm{~h}$ and a loading rate of $0.08 \mathrm{~kg}-\mathrm{N} / \mathrm{m}^{3} / \mathrm{d}$.

Effects of DO fluctuation on nitrogen removal Effects of limited aeration period on the $\mathrm{T}-\mathrm{N}$ removal rate using the aeration- 
limited control equipment (Fig. 2) were investigated under sequential aeration/nonaeration conditions with $\mathrm{T} 1 / \mathrm{T} 2$ (T1: aeration time, T2: non-aeration time) controlled at $2 / 10,4 / 8,8 / 4,6 / 6,10 / 50$, and 20/40 min. Effluent quality under each T1/T2 condition was measured, and the $\mathrm{T}-\mathrm{N}$ removal rate was obtained. Treatments were carried out at a retention time of $6 \mathrm{~h}$ and a loading rate of $0.08 \mathrm{~kg}-\mathrm{N} / \mathrm{m}^{3} / \mathrm{d}$.

\section{Nitrogen removal performance of aeration- limited process}

Effects of ammonium load on nitrogen removal The effects of ammonium loading rate on nitrogen removal was investigated under the following three systems: aerationlimited control, continuous aeration, and using conventional activated sludge. The retention time was $4-24 \mathrm{~h}$ and the loading rate was $0.02-0.12 \mathrm{~kg}-\mathrm{N} / \mathrm{m}^{3} / \mathrm{d}$. The $\mathrm{T}-\mathrm{N}$ removal ratio was calculated from the water quality of the influent and the effluent under each set of conditions. Details are explained below.

1) Operation under aeration-limited conditions T1/T2 was controlled to be 20/40 min. The packing ratio of the pellets was $20 \%$ using a single tank shown in Fig. 2 .

2) Operation under continuous aeration conditions Dissolved oxygen by aeration was set to be at least $3.0 \mathrm{mg} / \mathrm{l}$ using a single tank shown in Fig. 2. The packing ratio of pellets was $20 \%$ of the reactor volume.

3) Operation using conventional activated sludge Activated sludge was added to the aeration tank shown in Fig. 3. The mixed liquor suspended solid (MLSS) was 2,000 $\mathrm{mg} / \mathrm{l}$ and the DO was set to be at least 3.0 $\mathrm{mg} / l$.

\section{Effect of $\mathbf{C} / \mathrm{N}$ ratio on nitrogen removal}

Using synthetic inorganic wastewater $\left(\mathrm{NH}_{4}-\mathrm{N} 20 \mathrm{mg} / l\right)$ with $\mathrm{C} / \mathrm{N}$ ratios of $1.4^{-4}$ at a retention time of $6 \mathrm{~h}, \mathrm{~T} 1 / \mathrm{T} 2$ was controlled at $20 \mathrm{~min} / 40 \mathrm{~min}$ using aeration-limited control. The packing ratio of pellets was $20 \%$ of the reactor volume. Water quality of influent and effluent was measured, and the T-N removal ratio was calculated.

All experimental treatments were carried out for 1-2 weeks under each condition at 20
${ }^{\circ} \mathrm{C}$, and the nitrogen removal performance was evaluated when a ratio of nitrogen removal had stabilized.

\section{Analytical method}

Ammonium concentrations were measured by a colorimetric method using the indophenol method. Nitrite and nitrate concentrations were determined by ion chromatography (IC7000, Yokogawa Analytical Systems, Tokyo). T-N concentration was calculated from the sum of ammonium nitrogen, nitrite nitrogen, and nitrate nitrogen concentrations.

Counts of viable nitrifying and denitrifying bacteria in the carrier were measured by a method previously reported by one of the authors. ${ }^{2)}$ Nitrifying counts were measured by most probable number (MPN) enumerations using two media, one containing $20 \mathrm{mg} / l$ (AL medium) and the other $100 \mathrm{mg} / \mathrm{l}$ (AH medium) of $\mathrm{NH}_{4}-\mathrm{N}$. Nitrifiers counted using the $\mathrm{AL}$ medium (AL counts) were characterized as ammonia-sensitive bacteria, and those counted using the $\mathrm{AH}$ medium (AH counts) were characterized as ammonia-insensitive

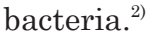

\section{RESULTS AND DISCUSSION}

\section{Optimization of operating conditions}

Effects of ORP on nitrogen removal The effects of ORP on nitrogen removal were examined. Treatment was carried out at a nitrogen loading rate of $0.08 \mathrm{~kg}-\mathrm{N} / \mathrm{m}^{3} / \mathrm{d}$ and a retention time of $6 \mathrm{~h}$, which are typical for a sewage treatment plant. The $\mathrm{C} / \mathrm{N}$ ratio of the influent was 4, which is a sufficient quantity for denitrification. The ORP of 0-60 $\mathrm{mV}$ is the boundary range of aerobic and anaerobic conditions; therefore, the ORP range was carried out at $0-250 \mathrm{mV}$. Results are shown in Fig. 4.

In aeration control by the lower limit and the upper limit of ORP, the ORP varied in a range shown by the bar in Fig. 4 for intervals of 20-30 min. This tended to improve the nitrogen removal with an increase of ORP.

The boundary of $0-60 \mathrm{mV}$, which is the critical point between aerobic and anaerobic atmospheres, was considered to be suitable for simultaneous nitrogen removal. However, this was not effective, and absolute anaerobic 


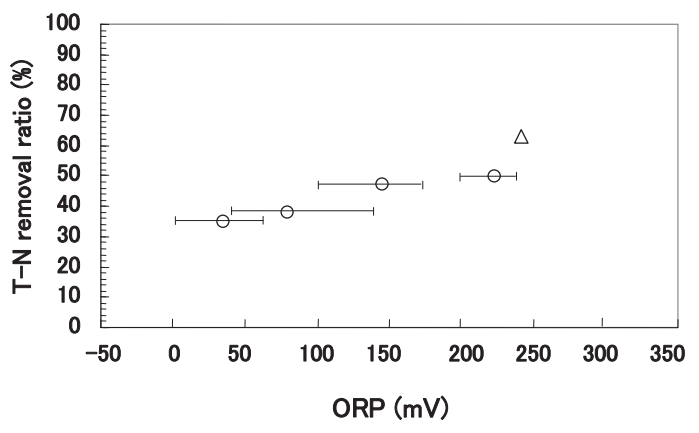

Fig. 4 Effects of ORP on nitrogen removal. ORP control

$\triangle$ continuous aeration

conditions were not indispensable for simultaneous nitrification and denitrification.

In contrast, nitrogen removal using continuous aeration without control of ORP is shown by the open triangles in Fig. 4. Nitrogen removal was $63 \%$ and ORP was 245 $\mathrm{mV}$. Improved nitrogen removal was achieved using continuous aeration. Therefore, further measurements, as described below, were taken to evaluate the effects of DO on nitrogen removal in continuous aeration.

Effects of DO on nitrogen removal Effects of DO on nitrogen removal in continuous aeration were examined for a DO of $0.2-4.0$ $\mathrm{mg} / \mathrm{l}$, a loading rate of $0.02-0.12 \mathrm{~kg}-\mathrm{N} / \mathrm{m}^{3} / \mathrm{d}$, and a $\mathrm{C} / \mathrm{N}$ ratio of 4 , as shown in Fig. 5 . Nitrogen removal at $0.12 \mathrm{~kg}-\mathrm{N} / \mathrm{m}^{3} / \mathrm{d}$ and 0.08 $\mathrm{kg}-\mathrm{N} / \mathrm{m}^{3} / \mathrm{d}$ was higher than at $0.02 \mathrm{~kg}-\mathrm{N} / \mathrm{m}^{3} /$ d. High nitrogen removal of $60-65 \%$ was obtained at $0.08 \mathrm{~kg}-\mathrm{N} / \mathrm{m}^{3} / \mathrm{d}$ for a DO of $0.6^{-4}$ $\mathrm{mg} / l$. Influent $\mathrm{NH}_{4}-\mathrm{N}$ could be removed to be as low as $2 \mathrm{mg} / l$. Slightly aerobic conditions in which the DO ranged from 0.02 to $0.6 \mathrm{mg} /$ $l$ resulted in highly variable rates of nitrification, and the $\mathrm{T}-\mathrm{N}$ removal ratio markedly decreased. Although complete nitrification occurred at a DO of 1-4 $\mathrm{mg} / \mathrm{l}$, denitrification declined and $\mathrm{T}-\mathrm{N}$ removal ratio was not sufficient. Denitrification is therefore considered to be the limiting factor. The low denitrification rate is believed to be due to conditions that were not completely anoxic, and therefore the DO fluctuations were examined.

Effects of DO fluctuations on nitrogen removal The effects of DO fluctuations on nitrogen removal were examined using a limited aeration system which was used for continuous wastewater treatment by varying the DO by repeatedly switching from aeration to non-aeration and back again. Table 2 shows the $\mathrm{T}-\mathrm{N}$ removal ratio at aeration time $\mathrm{T} 1$ and non-aeration time $\mathrm{T} 2$ at a loading rate of $0.08 \mathrm{~kg}-\mathrm{N} / \mathrm{m}^{3} / \mathrm{d}$ and a $\mathrm{C} / \mathrm{N}$ of 4 . Nitrogen removal tended to be lower with decreasing T1/T2 intervals. Decreasing nitrogen removal at the short interval of RUN1 in Table 2 may be considered to be due to the increased lag time of shifting from denitrification to nitrification. DO and ORP

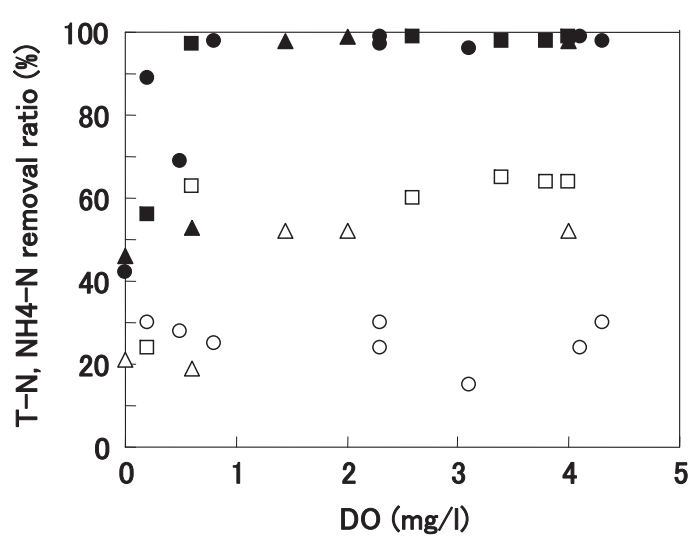

Fig. 5 Effects of DO on nitrogen removal using PEGentrapped activated sludge with continuous aeration equipment.

$\mathrm{T}-\mathrm{N}$ removal ratio at $0.02 \mathrm{~kg} / \mathrm{m}^{3} / \mathrm{d}$

$\square$ T-N removal ratio at $0.08 \mathrm{~kg} / \mathrm{m}^{3} / \mathrm{d}$

$\triangle \mathrm{T}-\mathrm{N}$ removal ratio at $0.12 \mathrm{~kg} / \mathrm{m}^{3} / \mathrm{d}$

- $\mathrm{NH}_{4}-\mathrm{N}$ removal ratio at $0.02 \mathrm{~kg} / \mathrm{m}^{3} / \mathrm{d}$

$\mathrm{NH}_{4}-\mathrm{N}$ removal ratio at $0.08 \mathrm{~kg} / \mathrm{m}^{3} / \mathrm{d}$

- $\mathrm{NH}_{4}-\mathrm{N}$ removal ratio at $0.12 \mathrm{~kg} / \mathrm{m}^{3} / \mathrm{d}$

Table 2 Nitrogen removal rate at aeration time T1 and non-aeration time T2 using PEG-entrapped activated sludge with aeration-limited control under a loading rate of $0.08 \mathrm{~kg}-\mathrm{N} / \mathrm{m}^{3} / \mathrm{d}$ and $\mathrm{C} / \mathrm{N}$ ratio of 4 .

\begin{tabular}{cccc}
\hline Run & $\begin{array}{c}\text { Aeration time } \\
\text { T1 (min) }\end{array}$ & $\begin{array}{c}\text { Non-aeration } \\
\text { time T2 }(\min )\end{array}$ & $\begin{array}{c}\text { T-N removal } \\
\text { ratio }(\%)\end{array}$ \\
\hline 1 & 2 & 10 & 23 to 28 \\
2 & 4 & 8 & 35 to 41 \\
3 & 8 & 4 & 49 to 75 \\
4 & 6 & 6 & 54 to 59 \\
5 & 10 & 50 & 69 to 99 \\
6 & 20 & 40 & 83 to 90 \\
\hline
\end{tabular}


at a T1/T2 of 20/40 min are shown in Fig. 6. DO varied from $0-7.5 \mathrm{mg} / l$. Effluent nitrogen and nitrogen removal ratio are shown in Fig. 7. Influent nitrogen could be removed to be as low as $1-4 \mathrm{mg} / l$, and the $\mathrm{T}-\mathrm{N}$ removal ratio was over $80 \%$. These results indicate the possibility of improving the nitrogen removal ratio using an aeration-limited process by alternating between aeration and nonaeration conditions.

\section{Nitrogen removal performance of aeration- limited process}

Effects of ammonium load on nitrogen removal The effects of ammonium load on nitrogen removal were examined using an aeration-limited process under conditions of $\mathrm{T} 1 / \mathrm{T} 2=20 / 40 \mathrm{~min}$. To estimate removal efficiency, three methods were compared: an aeration-limited method, a continuous aeration method, and a conventional activated sludge method.

Figure 8 shows that a good quality of effluent was obtained when the system was operated at a loading rate of 0.08 to 0.12 $\mathrm{kg}-\mathrm{N} / \mathrm{m}^{3} / \mathrm{d}$. However, it declined at a loading rate of $0.02 \mathrm{~kg}-\mathrm{N} / \mathrm{m}^{3} / \mathrm{d}$. It is believed that carbon for denitrification may be consumed by denitrifiers in aerobic conditions at very low ammonium loads. Consumption of organic carbon during the aeration period is considered to be constant under each set of conditions, so that the carbon for denitrification decreased at low ammonium loads.

As shown in Fig. 8, the aeration-limited process had higher performance than other methods. Nitrification can occur in the surface layers (aerobic zone) of pellets where oxygen is available, whereas denitrification can occur in deeper layers (anoxic zone) where the DO is close to zero. Using the aeration-limited process results in an increase in the DOgradient area between the aerobic zone and the anoxic zone, and therefore treatment performance can be enhanced. The improvement in these methods is providing separate areas for nitrifiers and denitrifiers, which results in increased rates of nitrogen removal by using an aeration-limited process.

In PEG-entrapped activated sludge, bacteria leakage, growth at the pellet surface,

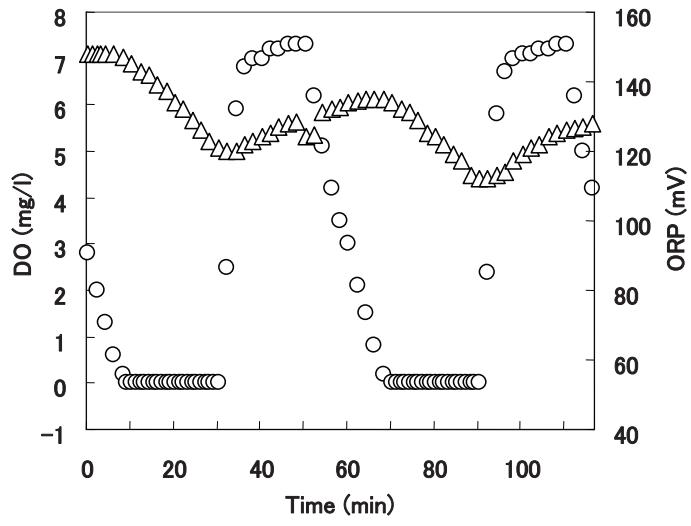

Fig. 6 Time course of DO and ORP using aerationlimited control.

DO

$\triangle \mathrm{ORP}$

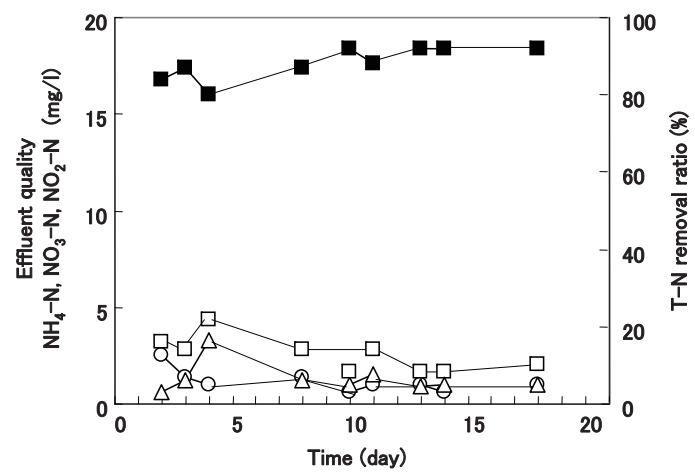

Fig. 7 Effluent nitrogen and nitrogen removal ratio using aeration-limited control.

$\bigcirc \mathrm{NH}_{4}-\mathrm{N}, \triangle \mathrm{NO}_{3}-\mathrm{N}$,

$\square \mathrm{T}-\mathrm{N}, \square \mathrm{T}-\mathrm{N}$ removal rate

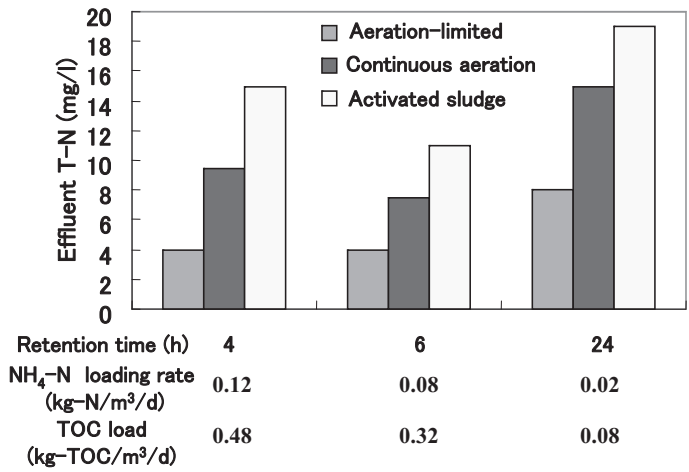

Fig. 8 Effects of ammonium loading rate on nitrogen removal using aeration-limited, continuous aeration, and conventional activated sludge methods at $\mathrm{C} / \mathrm{N}$ ratio of 4 . 
and growth of free cells in the liquid phase must be considered. However, these effects were found to be negligible, as evidenced by the amount of suspended solids (SS) in the effluent, which was less than $32 \mathrm{mg} / l$.

Counts of viable bacteria in the immobilized activated sludge and activated sludge are shown in Table 3. Values in parentheses are the counts per carrier, and the upper value is calculated relative to the volume of the reactor. As shown in Table 3, AL counts are higher than AH counts. Previously, it was found that nitrifying bacteria were much more readily recovered from most sewage and nightsoil treatment sludge by an $\mathrm{AL}$ medium than by an $\mathrm{AH}$ medium, suggesting that nitrifying bacteria sensitive to higher concentrations of $\mathrm{NH}_{4}-\mathrm{N}$ may be predominant in most wastewater treatment facilities. ${ }^{11,12}$ We found the same pattern in this experiment.

AL counts in activated sludge were $10^{6}-10^{7}$ cells $/ \mathrm{m} l$, and those in immobilized PEGentrapped activated sludge was higher at $10^{6}-10^{8}$ cells $/ \mathrm{m} l$. AL counts were the highest at $4 \mathrm{~h}$ of retention time in each process. There was a sufficient number in these experiments, which is the first reported finding, to the best of our knowledge. ${ }^{2)}$ The number of denitrification bacteria was higher at $6 \mathrm{~h}$ of retention time under both systems of continuous aeration and conventional activated sludge. The growth is believed to be aerobic growth using acetate. We plan to cultivate pellets under aerobic conditions and measure simultaneous nitrogen removal with high concentrations of denitrifying bacteria.

Effects of $\mathrm{C} / \mathrm{N}$ ratio on nitrogen removal The effects of $\mathrm{C} / \mathrm{N}$ ratio on nitrogen removal were examined using an aeration-limited process. Continuous treatment was performed with $\mathrm{T} 1 / \mathrm{T} 2=20 / 40 \mathrm{~min}$ and a $\mathrm{C} / \mathrm{N}$ ratio of 1.4-4. The effects of $\mathrm{C} / \mathrm{N}$ ratio on nitrogen removal are shown in Fig. 9. The nitrogen removal ratio was $80 \%$ at a $\mathrm{C} / \mathrm{N}$ ratio of over 2.5 . The nitrogen removal ratio was decreased as the $\mathrm{C} / \mathrm{N}$ ratio decreased below 2.5 . We plan to test a system having a $\mathrm{C} / \mathrm{N}$ ratio below 2.5. Excessive carbon is believed to be consumed in aeration of aerobic biological oxidation in aeration-limited processes. To decrease consumption of carbon under
Table 3 Counts of viable bacteria in PEG-entrapped activated sludge and activated sludge.

\begin{tabular}{|c|c|c|c|c|}
\hline \multirow{2}{*}{\multicolumn{2}{|c|}{$\begin{array}{l}\mathrm{R} \\
(\mathrm{h}\end{array}$}} & \multicolumn{2}{|c|}{ Nitrifying bacteria } & \multirow{2}{*}{$\begin{array}{l}\text { Denitrifying } \\
\text { bacteria } \\
(\text { cells } / \mathrm{m} l)\end{array}$} \\
\hline & & $\begin{array}{c}\text { AL counts } \\
\text { (cells/ml) }\end{array}$ & $\begin{array}{l}\text { AH counts } \\
\text { (cells/ml) }\end{array}$ & \\
\hline \multirow{3}{*}{$\begin{array}{l}\text { Aeration- } \\
\text { limited } \\
\text { process } \\
\text { using } \\
\text { pellets }\end{array}$} & 24 & $\begin{array}{c}2.5 \times 10^{6} \\
\left(1.2 \times 10^{7}\right)\end{array}$ & $\begin{array}{c}6.9 \times 10^{6} \\
\left(3.5 \times 10^{7}\right)\end{array}$ & $\begin{array}{c}3.0 \times 10^{6} \\
\left(1.5 \times 10^{7}\right)\end{array}$ \\
\hline & 6 & $\begin{array}{c}2.2 \times 10^{6} \\
\left(1.1 \times 10^{7}\right)\end{array}$ & $\begin{array}{c}1.2 \times 10^{5} \\
\left(5.8 \times 10^{5}\right)\end{array}$ & $\begin{array}{c}1.5 \times 10^{7} \\
\left(7.3 \times 10^{7}\right)\end{array}$ \\
\hline & 4 & $\begin{array}{r}2.0 \times 10^{8} \\
\left(1.0 \times 10^{9}\right) \\
\end{array}$ & $\begin{array}{c}4.5 \times 10^{7} \\
\left(2.3 \times 10^{8}\right) \\
\end{array}$ & $\begin{array}{c}2.0 \times 10^{7} \\
\left(1.0 \times 10^{8}\right) \\
\end{array}$ \\
\hline \multirow{3}{*}{$\begin{array}{l}\text { Continuous } \\
\text { aeration } \\
\text { using } \\
\text { pellets }\end{array}$} & 24 & $\begin{array}{r}7.4 \times 10^{6} \\
\left(3.7 \times 10^{7}\right) \\
\end{array}$ & $\begin{array}{c}1.6 \times 10^{5} \\
\left(8.0 \times 10^{5}\right) \\
\end{array}$ & $\begin{array}{r}3.1 \times 10^{6} \\
\left(1.6 \times 10^{7}\right) \\
\end{array}$ \\
\hline & 6 & $\begin{array}{c}1.5 \times 10^{6} \\
\left(7.5 \times 10^{7}\right)\end{array}$ & $\begin{array}{c}6.9 \times 10^{6} \\
\left(3.5 \times 10^{7}\right)\end{array}$ & $\begin{array}{c}2.0 \times 10^{8} \\
\left(1.0 \times 10^{9}\right)\end{array}$ \\
\hline & 4 & $\begin{array}{c}7.6 \times 10^{7} \\
\left(1.5 \times 10^{8}\right) \\
\end{array}$ & $\begin{array}{r}4.5 \times 10^{5} \\
\left(2.2 \times 10^{6}\right) \\
\end{array}$ & $\begin{array}{c}3.0 \times 10^{7} \\
\left(1.5 \times 10^{8}\right) \\
\end{array}$ \\
\hline \multirow{3}{*}{$\begin{array}{l}\text { Activated } \\
\text { sludge }\end{array}$} & 24 & $3.5 \times 10^{6}$ & $8.3 \times 10^{3}$ & $5.8 \times 10^{6}$ \\
\hline & 6 & $1.1 \times 10^{7}$ & $6.5 \times 10^{3}$ & $1.2 \times 10^{8}$ \\
\hline & 4 & $3.3 \times 10^{7}$ & $5.8 \times 10^{5}$ & $6.0 \times 10^{6}$ \\
\hline
\end{tabular}

Values in parentheses $(\mathrm{N})$ are the counts of viable bacteria per carrier, and the upper value $\left(\mathrm{N}^{\prime}\right)$ is calculated with respect to the volume of the reactor. $\mathrm{N}^{\prime}=\mathrm{N} \times$ packing ratio $/ 100=\mathrm{N} / 5($ cells $/ \mathrm{m} l)$

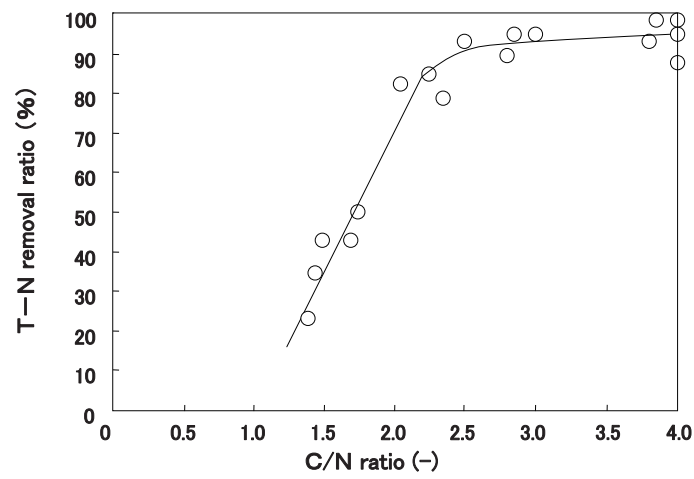

Fig. 9 Effects of $\mathrm{C} / \mathrm{N}$ ratio on nitrogen removal using aeration-limited control.

aeration conditions, we are currently trying feedback aeration-control according to the water quality of the effluent.

\section{CONCLUSION}

Effects of ORP, DO, load, and $\mathrm{C} / \mathrm{N}$ ratio on nitrogen removal ratio were examined to clarify operational factors affecting simultaneous nitrification and denitrification using PEG-entrapped activated sludge. Simultaneous nitrification and denitrification treat- 
ment using PEG-entrapped activated sludge was observed in single reactor. The following points summarize the major findings of these experiments.

(1) In single-tank nitrification and denitrification treatment, ORP was not significant and absolute anaerobic conditions were not indispensable.

(2) Nitrogen removal ratio was not improved even if slightly aerobic conditions of DO in a range of $0.2-0.6 \mathrm{mg} / l$ occurred under continuous aeration.

(3) Fluctuations in DO in a range of $0-7.5$ $\mathrm{mg} / l$ were effective, influent nitrogen could be removed to be as low as $1-4 \mathrm{mg} / l$, and nitrogen removal was over $80 \%$. These results indicate the possibility of improving nitrogen removal by using aeration-limited processes by repeatedly alternating between aeration and non-aeration conditions.

(4) The nitrogen removal performance was highest for the aeration-limited process, less high for the continuous aeration process, and lowest for the activated sludge method, at a loading rate of $0.02-0.12 \mathrm{~kg}-\mathrm{N} / \mathrm{m}^{3} / \mathrm{d}$.

(5) To obtain nitrogen removal at $80 \%$ or more, the $\mathrm{C} / \mathrm{N}$ ratio of the influent should be over 2.5 using an aeration-limited process.

\section{REFERENCES}

1 ) Sumino, T., Nakamura, H., Mori, N., and Kawaguchi, Y.: Immobilization of nitrifying bacteria by polyethylene glycol prepolymer, J. Ferment. Bioeng., 73, 37-42 (1992)

2 ) Sumino, T., Mori, N., Ogasawara, T., and Tanaka, K.: Growth characteristics and nitrification rate of nitrifying bacteria entrapped in pellets, Japanese J. Wat. Treat. Biol., 36(4), 173-181 (2000)

3 ) Hashimoto, N., and Sumino, T.: Wastewater treatment using activated sludge entrapped in polyethylene glycol prepolymer, J. Ferment. Bioeng., 86, 424-426 (1998)

4 ) Okayasu, Y., Abe, I., and Matsudo, Y.: Emission of nitrous oxide from high-rate nitrification and denitrification by mixed liquor circulating process and sequencing batch reactor process, Wat. Sci. Technol., 36, 39-45 (1997)
5 ) Masuda, S., Watanabe, Y., and Ishiguro, M.: Biofilm properties and simultaneous nitrification and denitrification in aerobic rotating biological contactors, Wat. Sci. Technol., 23, 1355-1363 (1991)

6 ) Kokufuta, E., Shimohashi, M., and Nakamura, I.: Simultaneously occurring nitrification and denitrification under oxygen gradient by polyelectrolyte complex-coimmobilized Nitrosomonas europaea and Paracoccus denitrificans cells, Biotechnol. Bioeng., 31, 382-384 (1998)

7 ) Nakano, K., Iwasawa, H., Ito, O., Lee, T., and Matsumura, M.: Simultaneous nitrificationdenitrification under constant dissolved oxygen condition by using two different immobilization carriers with specific oxygen transfer characteristics, Japanese J. Wat. Treat. Biol., 40(1), 29-35 (2004)

8 ) Sliekers, A.O., Derwork, N., Gomex, J.L.C., Strous, M., Kuenen, J.G., and Jetten, M.S.M.: Completely autotrophic nitrogen removal over nitrite in one single reactor, Wat. Res. 36, 2475-2482 (2002)

9 ) Lieu, P.K., Hatozaki, R., Homan, H., and Furukawa, K.: Single-stage nitrogen removal using anammox and partial nitritation (SNAP) for treatment of synthetic landfill leachate, Japanese $J$. Wat. Treat. Biol., 41(2), 103-112 (2005)

10) Lieu, P.K., Homan, H., Kurogi, A., Kawagoshi, Y., Fugii, T., and Furukawa, K.: Characterization of sludge from single-stage nitrogen removal using anammox and partial nitritation (SNAP), Japanese J. Wat. Treat. Biol., 42(2), 53-64 (2006)

11) Suwa, Y., Imamura, Y., Suzuki, T., and Urushigawa, Y.: Ammonia-oxidizing bacteria with different sensitivities to $\left(\mathrm{NH}_{4}\right)_{2} \mathrm{SO}_{4}$ in activated sludges, Wat. Res., 28, 15231532 (1994)

12) Suwa, Y., Sumino, T., and Noto, K.: Phylogenetic relationships of activated sludge isolates of ammonia oxidizers with different sensitivities to ammonium sulfate, J. Gen. Appl. Micobiol., 43, 373379 (1997)

(Submitted 2006. 9. 12)

(Accepted 2007. 5. 11) 